NBER WORKING PAPER SERIES

\title{
INFORMATION TECHNOLOGY AND RESEARCH AND DEVELOPMENT IMPACTS ON PRODUCTIVITY AND SKILLS: LOOKING FOR CORRELATIONS ON FRENCH FIRM LEVEL DATA
}

\author{
Nathalie Greenan \\ Jacques Mairesse \\ Agnes Topiol-Bensaid \\ Working Paper 8075 \\ http://www.nber.org/papers/w8075
NATIONAL BUREAU OF ECONOMIC RESEARCH
1050 Massachusetts Avenue
Cambridge, MA 02138 \\ January 2001
}

\begin{abstract}
A preliminary and shorter version of this study has appeared in French in Greenan, Mairesse and TopiolBensaid 1999. The views expressed herein are those of the authors and not necessarily those of the National Bureau of Economic Research.

(C) 2001 by Nathalie Greenan, Jacques Mairesse and Agnes Topiol-Bensaid. All rights reserved. Short sections of text, not to exceed two paragraphs, may be quoted without explicit permission provided that full credit, including $(\mathcal{C}$ notice, is given to the source.
\end{abstract}


Information Technology and Research and Development Impacts on Productivity and Skills: Looking for Correlations on French Firm Level Data

Nathalie Greenan, Jacques Mairesse and Agnes Topiol-Bensaid

NBER Working Paper No. 8075

January 2001

JEL No. D24, L63, O33

\begin{abstract}
The main objective of the study is descriptive. We set out to explore the (cor)relations between five IT and R\&D indicators and measures of labor and total factor productivity, average wage and skill composition, on four panel data samples of French manufacturing and services firms over the two five years periods 1986-1990 and 1990-1994. Our first indicator is the ratio of the gross book value of office and computing equipment to the gross book value of total physical assets. The four other indicators are respectively constructed using very detailed information on the occupational and skill structure of the firm; they are the shares in the total number of employees of the four categories of specialized workers that we can gather under the headings of "computer staff", "electronics staff", "research staff" and "analysis staff". The only significant finding in the time-series dimension of the data is the relation between an increase in all five indicators and a decrease in the share of blue collar-workers, while in the cross-sectional dimension of the data we observe strong evidence of positive correlations with productivity, average wage and the share of administrative managers, as well as negative ones with the share of blue-collar workers.
\end{abstract}

Jacques Mairesse

Crest, Insee, Timbre J322

15, Boulevard Gabriel Peri

92245 Malakoff Cedex

FRANCE

and NBER

mairesse@ensae.fr
Nathalie Greenan

Agnes Topiol-Bensaid 


\section{Introduction}

Over the past twenty to thirty years Information Technology (IT) has spread rapidly throughout modern industrial economies. ${ }^{1}$ The impacts of this development on characteristics of the firm and its performances are obviously many and important. We specially expect that the adoption of IT and the increasing intensity of its use transforms the firm production function and modifies both the composition and quality of its factors of production. Considering first the direct effects of these changes, we may say that the firm capital stock includes a growing volume of computer equipment (with increasingly high performances), while machines and other equipment are more and more dependent on electronic components and computer software. Moreover, in order to manage and maintain the new installations, firms must call upon specialized staff, and at the same time, IT using workers must acquire specific knowledge and skills. But there are also various indirect consequences. Most firms as the same time as they invest in IT, change their production, administrative and sales structures and adapt their organisation. This co-evolution does not necessarily mean causality. IT can be used in many ways, conservative ones as well as innovative ones. The simultaneity of changes in technology, skills and organization may be related to various causes where the characteristics of technologies play a permissive part more than an active one. The impacts of IT may thus vary in relation to different organizational configurations. Overall, however, we expect that IT enables the firms to improve their performances, particularly in terms of labor and total factor productivity, and goes along with an upgrading of workers skills.

The main objective of the present study is descriptive. We set out to explore the (cor)relations between IT and productivity and skills, and whether these relations are statistically significant according to expectations and correspond to impact coefficients which appear economically meaningfull. We also engage, by way of comparison and as a form of calibration, in a parallel investigation about Research and Development (RD) and its relationships with productivity and skills, domain in which the type of issues are quite similar but which has been more widely studied until recently. For lack of better measures, we proxy the intensity of IT use in the firm with three indicators: the share of "computer equipment" in the firm total capital, and the shares of "computer" and "electronics" specialists in the firm total number of employees. Computer specialists are in

1 France, contrary to a rather widely accepted view, has not been a laggard in this evolution. Statistics based on employee level data (or matched employer-employee level data) have shown that in fact the diffusion of IT has been generally quite fast in most sectors, more particularly in financial and business services. See for example GreenanMairesse 2000. 
charge of maintenance, servicing and development tasks linked to the use of computers, whereas electronics specialists perform similar functions on machines incorporating electronic components (from cash registers to automated manufacturing systems). Although very imperfect, these two indicators hopefully complement each other, the first one giving a measure of "visible IT" and the second of "invisible IT" (that is embodied in conventional equipment). We also consider two similar indicators to proxy for the intensity of efforts by the firm in research and innovation activities: the share of "RD" staff engaged in research and development activities proper and the share of workers in more informal design and analytical activities, that we shall call "analysis" staff. In the end, what we do in this study amounts to the specification and estimation of various sets of very simple firm level regressions relating the five IT and RD indicators to productivity and skill composition variables.

More precisely, we specify and estimate these regressions both in the cross-sectional and in the time-series dimensions of our data, trying to assess the statistical significance and economic magnitude of the impact coefficients of interest from both between firm differences and within firm changes, that is from the (simple or partial) correlations in the levels of variables and in the changes in levels of variables (their growth rates if they are in log form). The analysis is performed on a large panel data sample of French firms over the years 1986 to 1994 (more precisely on four balanced samples for manufacturing and the services, and the two five years periods 1986-1990 and 1990-1994 separately). As we shall see, our results are quite different in the two dimensions of the data, which is rather typical in econometric panel data studies as ours. They are mostly significant in the cross-section, showing sizeable orders of magnitude and interesting differences or likenesses across IT and RD indicators, manufacturing and services and periods. However before presenting our results, it is useful to give further information on our data and method of analysis.

\section{1 - GENERAL FRAMEWORK}

\section{1 - The Data: Computerization and Research Indicators and Other Variables}

The detailed balance sheet information that can be gathered from the INSEE system of firm statistics SUSE: (“Système Unifié de Statistiques d'Entreprises”) enables us to construct our first indicator of firm computerization (PKI), as the proportion of the gross book value of assets in office 
and computing equipment (KI) to the gross book value of total physical (or tangible) assets (K). Computers and peripheral equipment form the major part of this indicator, which also includes other office equipment (such as furniture, photocopier, etc.). ${ }^{2}$

From the SUSE information on firm current accounts, we also know the firm value added (VA) and its total labor compensation (WL), from which, by dividing by the total number of employees (L), we obtain an estimate of labor productivity (VA/L) and one of average labor cost or average wage rate $(\mathrm{W})$. Based on these two estimates, we also (implicitly) derive a measure of average labor cost adjusted for labor quality and capital intensity (WA), and a measure of total factor productivity (TFP). WA and TFP are (implicitly) computed by introducing in the regressions, which we perform on $\mathrm{W}$ and $\mathrm{VA} / \mathrm{L}$, a set of control variables for skill composition in four major categories - (CP), (CA), (EP) and (EA) as defined below- and for capital intensity measured by the average gross book value of physical assets per employee $(\mathrm{K} / \mathrm{L}){ }^{3}$

Our other main source of information is "l'Enquête sur la Structure des Emplois" ESE (i.e., the employment structure survey) which provides a very detailed breakdown of firm labor force that distinguishes about 270 occupation and skill categories (known as the nomenclature PCS of "Professions et Categories Socio-professionnelles"). Our two other indicators of firm computerization PINF and PELEC and our two indicators of firm research PRD and PETU are based on this classification. They are respectively constructed as the shares in the total numbers of employees (L) of the four categories of specialised workers that we can gather under the headings of "computer staff" ("Informaticiens"), "electronics staff" ("Electroniciens"), "research staff" ("Chercheurs") and "analysis staff" ("Chargés d'Etudes"). ${ }^{4}$

Clearly, for a number of reasons, PKI, PINF and PELEC are very rough indicators of firm computerization. PKI does not reflect the extremely rapid increase in efficiency of computer

\footnotetext{
2 For more details on SUSE and the definition of PKI, see Appendix A1.1. In fact the detailed breakdown of firm balance sheets allowing the measure of PKI is only available for a representative sample of firms and not the full population of firms in SUSE, and our study is based on this sample.

${ }^{3}$ We have also computed an alternative measure of TFP using the average wage $\mathrm{W}$ as a control variable for skill in the $\mathrm{VA} / \mathrm{L}$ regressions (instead of the four skill composition variables), and thus making the extreme assumption that all the variability in the average wage or labor cost $\mathrm{W}$, both between and within firms, reflects the variability of labor quality. For a discussion of the significance of this hypothesis and its extreme nature, see Greenan-Mairesse, 2000. To cut on the large number of results already shown here, we do not report on the estimates obtained with this alternative TFP measure; these estimates, as could be expected, tend to be smaller and less significant than the ones obtained with our prefered measure, but do not contradict our qualitative findings and tentative conclusion on the range of IT and RD impacts on productivity.

${ }^{4}$ For more details on ESE and the definition of PINF, PELEC, PRD and PETU, see Appendix A1.2.
} 
equipment, and also does not cover software expenditures nor computer related personnel training expenditures. PINF and PELEC are likely to be underestimated since tasks involving management and maintenance of computer or electronic equipment may be assigned to workers which are not registered as full time computer or electronics specialists, or because these tasks may be externalised in part to outside services. ${ }^{5}$

PRD and PETU are probably more satisfactory indicators of firm research and innovative activities. The first one seems well in accordance with the standard and rather strict definition of Research and Development (RD) personnel while the second one corresponds to a wider definition of research, taking into account workers involved in less formal innovative activities as those taking place in the service sector or in the production of localized knowledge. 6

We also use the information from the ESE to characterize the overall skill composition of the firm labor force in four large categories, noted as (CP), (CA), (EP) and (EA). We define these categories along the two following dimensions: conception and management positions (C) versus execution ones $(\mathrm{E})$, and production activities $(\mathrm{P})$ versus non production and administrative ones $(\mathrm{A})$; in other words, we make the usual distinctions between engineers and administrators, and blue and white collar workers. Our specialised groups of IT and RD employees can also be broken down according to these overall skill categories. In fact, in order to avoid "double counting" type biases in our regression analyses on skill composition, we have excluded from our measures of firm overall skill composition PCP, PCA, PEP and PEA the corresponding numbers of IT and RD employees. ${ }^{7}$

Finally, by matching the relevant SUSE and ESE data bases for the years 1986 to 1994, we have been able to contruct four balanced samples for the two five years periods 1986-1990 and 19901994, and for the manufacturing and services sectors separately. These samples consist of about 3000 medium and large sized firms (of more than 20 salaried employees) in manufacturing and about 2500 in services; and, with respectively 1,4 millions and 0,7 millions employees in 19861990, and 1,2 millions and 0,6 millions employees in 1990-1994, they cover roughly $25 \%$ to $30 \%$

\footnotetext{
5 However, going in the opposite direction, workers not directly involved in these tasks may be gathered under the headings of computer and electronics staff as we can define them. In particular electricity and electronics maintenance personnel are not separated even at the most detail level of the PCS classification.

${ }^{6}$ In fact we have been able to check that the ESE information on the numbers of research workers, as we used it here, is largely consistent with that available in the annual surveys on RD expenditures, which are performed according to the criteria of the Frascati manual (see Mairesse-Bensaid-Greenan, 2000).
} 
and $15 \%$ to $20 \%$ of the total employment (for the firms with more than 20 salaried employees) in these two sectors in the two periods. ${ }^{8}$

\section{2 - The Method : Cross-Sectional and Time-Series Regressions}

Our main purpose is to explore systematically, but as simply as possible, the relations between firm computerization and research, as proxied by the five indicators PKI, PINF, PELEC, PRD and PETU, and firm characteristics of productivity, average wage and skill structure as measured by the six variables VA/L (or TFP), W (or WA), PCP, PCA, PEP and PEA. We choose to regress separately these six variables on our five indicators, thus running a total of 30 regressions for each of our four samples of manufacturing and services firms over the two five years periods 1986-1990 and 1990-1994. In the regressions relative to the four skill variables we only include firm size and industry dummies as control variables, while in the productivity and average wage regressions we also control for capital intensity $\mathrm{K} / \mathrm{L}$ and skill composition (as measured by the four skill variables). ${ }^{9}$ Thus we can simply test whether the estimated regression coefficients of our five indicators are statistically significant or not, and, if they are, tentatively assess the magnitude of impacts to which they might correspond. More precisely, we try to look for the existence and strenght of such impacts in both the cross-sectional and time-series dimensions of the data, by considering "between firm" and "within firm" regressions, that is respectively regressions in the average firm levels $\left(\mathrm{x}_{\mathrm{i}}\right)$ and $\left(\mathrm{y}_{\mathrm{i}}\right)$ of explanatory variables and variables to be explained, and regressions in the corresponding firm changes $\left(x_{i t}-x_{i}\right)$ and $\left(y_{i t}-y_{i}\right)$. We also try, in more unusual fashion, to relate the average firm levels and changes $\left(\mathrm{x}_{\mathrm{i}}\right)$ and $\left(\mathrm{y}_{\mathrm{it}}-\mathrm{y}_{\mathrm{i} .}\right) .{ }^{10}$.

\footnotetext{
${ }^{7}$ In Tables 1 and 2 in the text, giving respectively the average values (in \%) of PINF, PELEC, PRD and PETU and that of PCP, PCA, PEC and PEA, one can check that the total sum of these shares is indeed equal to $100 \%$. In Table 2 , the averages of PCP, PCA, PEP and PEA are also shown in parentheses before correction for double counting.

${ }^{8}$ For some details on the matching of SUSE and ESE data bases and the construction of the samples, see BensaidGreenan-Mairesse 1997, in which we used comparable procedures. It should be noted that we excluded from manufacturing and the service sectors the "supply" industries producing computers and electronic equipment, and providing computing and research services. These very rapidly growing industries, in which IT and RD personnel have a central role, would require a particular study.

${ }^{9}$ We have also runned the regressions on the four skill variables with capital intensity as an additional control variable, with results remaining qualitatively the same.

${ }^{10}$ This is what can be done by introducing in the within firm regressions another term interacting the average levels $\left(\mathrm{x}_{\mathrm{i} .}\right)$ and a time trend (i.e., a term of the form $(\mathrm{t}-\overline{\mathrm{t}}) \mathrm{x}_{\mathrm{i}}$, where $\mathrm{t}$ stands for year $\mathrm{t}$ and is mean centered). Note that the within
} 
There are in fact a number of ways to perform the betweeen and within firm type regressions, which are not necessarily always strictly identical but lead in our case to very similar results. Usually the two types of regressions are estimated separately, but we choose here to compute them as an overall regression. ${ }^{11}$ What we did in practise is precisely the following. As a first step we took the logarithms of our three variables in ratio type form, that is LVA/L, LK/L and LW (where the "front letter" L stands for logs), but kept the other variables, as we computed them, in terms of shares or proportions, that is the four skill variables PCP, PCA, PEP and PEA, and five indicators PKI, PINF, PELEC, PRD and PETU (where the "front letter" P stands for proportion). The main advantage of using logs for the ratio variables is to approximately "normalize" their distribution, and thus correct to a large extent the productivity and average wage regressions for heteroscedascity. Another reason is in allowing us to directly interpret the productivity regressions (controlling for capital intensity and skills) as being specifications of a Cobb-Douglas production function extended to IT and RD related factors, in addition to overall labor and capital indicators. ${ }^{12}$ Our second step was to calculate the firm means $\left(x_{i}\right)$ and deviations to the means $\left(x_{i t}-x_{i}\right)$ just for the first and last years of each period (1986 and 1990, 1990 and 1994). ${ }^{13}$ The last step was to run overall regressions (30 per sample) of the form:

$$
\mathrm{y}_{\mathrm{it}}=\alpha \mathrm{x}_{\mathrm{i} .}+\beta\left(\mathrm{x}_{\mathrm{it}}-\mathrm{x}_{\mathrm{i} .}\right)+\gamma(\mathrm{t}-\overline{\mathrm{t}}) \mathrm{x}_{\mathrm{i} .}+\mathrm{a}(\mathrm{t}-\overline{\mathrm{t}})+\mathrm{b} \cdot \operatorname{DSECT}+\mathrm{c} \cdot \text { DTAIL }+\mathrm{d}\left(\mathrm{z}_{\mathrm{it}}-\mathrm{z}_{\mathrm{i} .}\right)+\mathrm{ez}_{\mathrm{i} .}+\mathrm{u}_{\mathrm{it}}
$$

where $\alpha, \beta$, and $\gamma$ are our parameters of interest, expressing respectively the strenght of the conditional or partial correlations of $\left(x_{i}\right)$ and $\left(y_{i .}\right),\left(x_{i t}-x_{i}\right)$ and $\left(y_{i t}-y_{i .}\right)$ and $\left(x_{i}\right)$ and $\left(y_{i t}-y_{i}\right)$. The time trend $(t-\bar{t})$ and the firm industry and size dummies DSECT and DTAIL are included in all regressions, while $\left(z_{i t}-z_{i}\right.$. ) and $\left(z_{i}\right.$. $)$ are the within and between components of the other control variables z (capital intensity an skills) only included in the productivity and average

term $\left(\mathrm{x}_{\mathrm{it}}-\mathrm{x}_{\mathrm{i}}\right)$ may be correlated with the interaction term $(\mathrm{t}-\overline{\mathrm{t}}) \mathrm{x}_{\mathrm{i}}$. and hence the estimated within firm may be different in the presence of this term. However such correlation should be weak when the within regression also includes time dummies as it does usually. We have checked that indeed our within firm estimates remained practically unchanged if we included or not the interaction term (even when this term happened to be statistically significant, which is very rarely the case).

11 This is equivalent since the between and within terms $\left(\mathrm{x}_{\mathrm{i} .}\right)$ and $\left(\mathrm{x}_{\mathrm{it}}-\mathrm{x}_{\mathrm{i} .}\right)$ are uncorrelated ("orthogonal").

12 It is also possible to look at the other regressions as some forms of associated factor demand equations.

${ }^{13}$ In this case the means are equal to the half sum of the first and last year values, and the deviations to the means are equal to half the long differences (the differences between the last and first year values). Ignoring the intermediate years is just for the sake of maximum simplificity with little change in our estimates. 
wage regressions. ${ }^{14}$ In addition to these exploratory regressions where $\mathrm{x}$ stands for each of the IT and $\mathrm{RD}$ indicators in turn, we have also rerun regressions including all five indicators together, in order to better assess their overall contribution.

\section{2 - BASIC RESULTS}

The basic results of our work are summarised in Tables 1 to 6 in the text, and supplemented by the additional tables in the Appendices 2 to 5. Tables 5 and 6 give an overall view of the main findings of our systematic regression analyses, while more detailed estimates are recorded in the Appendices (Tables A3-1 to A3-5, A4-1 and A4-2, and A5). Tables 1 to 4 provide some statistical background by showing the average shares of workers in our four specialised groups of computer and research related occupations as well as among our four general skill categories.

\section{1 - IT and RD indicators and skill composition variables : the contrast between manufacturing and services}

Average employment numbers overall and in the four categories of administrators, engineers, and white and blue collar workers (CA,CP, EA and EP), and, within these four skill categories, the shares of what we called computer, electronics, research and analysis staff are given in Table 1 for our four samples. What we can gather from these detailed figures is summarised in Tables 2,3 and 4. In Table 2 we see that the overall shares of IT and RD related workers are much higher in manufacturing, with a total of about $17 \%$, than in the services, where they only amount to a total of 6 to $7 \%$. However, we can also see that the shares of computer workers strictly defined (PINF) are smaller in manufacturing than in the services, being respectively of about $1.5 \%$ as against nearly $3 \%$. This is confirmed by the average shares of computer capital in total capital (PKI), which are of the order of about $7 \%$ in manufacturing as compared to about twice as much $(14 \%)$ in the services

\footnotetext{
14 Since our regressions are restricted to two years only, the first and last ones of the sample periods, including the time trend $(\mathrm{t}-\overline{\mathrm{t}})$ is equivalent to having two years dummies (or one with the constant). We have five industry dummies (four with the constant) for the manufacturing as well the services samples, and likewise five size dummies (four with the constant). Note that we only kept three of our four skill variables in the productivity (LTFP) and average wage (LWA) regressions, since they add up very roughly to one (they do not add up exactly, being corrected for double counting with respect to PINF, PELEC, PRD and PETU).
} 
(see Table A2 in Appendix 2). ${ }^{15}$ The shares of research workers strictly defined (PRD), which are a sizeable $3 \%$ in manufacturing, are nearly negligible in the services $(0,2 \%)$, while the shares of electronics and analysis staffs are at least three times larger in manufacturing than in the services: $4, .5 \%$ as compared to $1.5 \%$, and $8 \%$ to $2.5 \%$.

In Table 3, we find the confirmation that blue collar workers remain by far the largest category in manufacturing with about $60 \%$ of total employment (before adjustment for "double counting"), while white collar workers and administrative managers are the two major categories in the services, with about $30 \%$ each of total employment. In Table 4 we observe that computer and electronics related activities are, to a large extent, still relying on blue or white collar workers (performing execution or operational tasks), who represent about one third of all computer related staff in manufacturing or in the services, and as much as about two third of all electronics related staff in manufacturing and about one third in the services. Research and analysis related activities are, on the contrary, relying basically on conception or management type of work, with only about 10 to $20 \%$ blue or white collar workers in these activities in manufacturing (and practically none in the services).

\section{2- The regression results: the contrast between the cross-sectional and time-series estimates}

A first look at our regressions results makes it clear that our estimates of IT and RD impact coefficients are in general quite significant in the cross-sectional dimension of the data, but rarely so in its time-series dimension. This can be clearly seen in the Tables A3-1 to A3-5 (one for the 24 regressions per indicator) of Appendix 3 and is summarized in Table 5, where a B or a $\mathrm{W}$ indicate that the between or within impact coefficient in the corresponding regression is significant (see footnote to Table). With only a few exceptions, all our between firm estimated $(\alpha)$ are highly statistically significant (at the $1 \%$ level of confidence), while only a minority of the corresponding

15 Note that the averages of PINF, PELEC, PRD, PETU, PCA, PCP, PEA and PEP given in Tables 2 and 3 are weighted averages computed on the base of the corresponding employment average (or total) numbers; they can differ noticeably from the unweighted averages (computed as the overall means of the firm corresponding ratios) recorded in Table A2 in Appendix 2. The largest difference is for PRD, with a weighted average of about 3\% in manufacturing, and the unweighted average of $2 \%$ only, which just express that large firms tend to do more research than smaller firms. For the share of computer capital PKI, however, the weighted (not given in the Tables) and the unweighted averages do not differ to the first decimal percentage point in none of our four sample, showing apparently no correlation with firm size. 
within firm estimated $(\beta)$ are statistically significant (even at the $10 \%$ level of confidence) and practically none of the estimated $(\gamma)$ are. ${ }^{16}$

These considerable discrepancies between the two types of estimations are not surprising. They are found in most studies. Insofar as one is willing to assume that the same econometric ("structural") model should account for both the cross-sectional and time-series correlations and variability of the explained and explanatory variables, such discrepancies may be rationalized in terms of various "specification errors", which would have different consequences and result in biases of varying seriousness according to the type of estimation. The variability over time (within firms) of the IT and RD indicators being significantly lower than across individual firms (between firms), non systematic or random measurement errors affecting them are far more likely to result in much larger biases in the time-series estimates than in the cross-sectional ones. ${ }^{17}$ It could thus be argued that this is a major reason why we find that the former are not generally significant, unlike the latter. It can also be argued, however, that the existence of specific factors to the firm, managerial, organizational or otherwise, is likely to explain, at least in part, the strength of the cross-sectional correlations. ${ }^{18}$ As we already indicated at the outset, we limit ourselves in the present study to a descriptive exploration which has not the ambition to elucidate the phenomena in their complexity and disentangle the problems raised by their observation and econometric modelling, but which hopefully can give us some insight and provide a useful basis for future analyses.

\section{3- The only significant finding in the time-series dimension: the decrease in the share of blue-collar workers in manufacturing}

In the time-series dimension of the data, there is no firm level evidence, or at best a very weak and unconvincing evidence, of a significant correlation between an increase in our IT and RD indicators and growth of productivity and average wage. The only clear indication of a significant relationship is that between an increase in all our five indicators and a decrease in the share of blue collar workers (PEP) in manufacturing. There is also a slight indication of a parallel link in the services sector between an increase in IT labor (as measured by PINF) and a decrease in the shares of blue and white collar workers. Such results can be directly viewed and interpreted in terms of "skill-

\footnotetext{
16 Setting $(\gamma=0)$ in the regressions (that is deleting the interaction term $\left.(\mathrm{t}-\overline{\mathrm{t}}) \mathrm{x}_{\mathrm{i}}\right)$ does not practically change the estimated $\beta$ (see footnote 10).

${ }^{17}$ On these points, see for example Mairesse 1990 and Griliches-Mairesse 1998.
} 
biased technological change" shifting the firm workforce distribution from lower to higher skilled jobs.

It is worthwhile noting that we would have had a somewhat different picture if we had not adjusted our four skill variables for double counting with respect to the shares of IT and RD employees. In Tables A4-1 and A4-2 in Appendix 4 we document the differences that can arise in the regressions relative to PINF and PRD, when we do not correct at all for double counting or when we correct only according to the indicator involved in the regressions under consideration (that is respectively PINF or PRD), and not broadly as we did (that is with respect to all four IT and RD labor indicators). We see in particular that we might have concluded to significant positive correlations over time in manufacturing between the share of engineers (PCP) and that of RD labor (PRD), or between the share of employees (PEA) and that of IT labor (PINF). We see also that our finding of a negative relation between the decrease in share of blue collars (PEP) in manufacturing and the increase in IT labor (PINF) would have been unaffected but not that of a similar relation with RD labor (PRD), which is not statistically significant in the absence of double counting adjustment. ${ }^{19}$

\section{4- In the cross-section, strong evidence of correlations with productivity and average wage...}

In the cross-sectional dimension of the data, the firm level evidence of positive and significant correlations between productivity and average wage and all our five IT and RD indicators is overwhelming. This is more precisely so for our total factor productivity (LTFP)and adjusted average wage (LWA) measures, since we explicitly control for firm differences in capital intensity and general skills (and for firm size and industry) in the regressions. ${ }^{20}$ This is so for both manufacturing and services and in the two periods of study, and nearly always at the (high) confidence level of $1 \%$. In Table 6 , we have interpreted and calibrated these correlations (and the corresponding regression coefficients) in terms of the total estimated impacts on firm productivity and average wage that we can compute for "joint differences" of one standard deviation in our three IT indicators and two RD indicators respectively. This gives us a better sense, and hopefully a more

\footnotetext{
${ }^{18}$ Such factors (through simultaneity or feedback effects) might also account for the finding of some significant timeseries correlations.

19 For an analysis of the double counting issue in the context of an analysis of the relation of RD and firm productivity, see Cuneo-Mairesse 1984, where it is shown that biases may be much less severe for the within firm estimates than for the between firm estimates. Note, however, that it is also possible that the adjustment for double counting may be in itself of source of measurement errors and hence result in biases in the opposite direction.
} 
realistic appreciation, of the magnitude of these correlations, allowing us to compare them on a likely basis.

More precisely, we have computed three variants or types of IT and RD estimated impacts or contributions. We show the three types of impacts in Table 6, but focus our comments here on the third type ones. Our first type of impacts are simply computed as the sum of the separate impacts of our three or two individual IT or RD indicators (for a difference of one standard deviation in each of them) ignoring completely their intercorrelations (that is based on their estimated coefficients in the regressions as performed on each of them separately). The second ones are also computed as the sum of separate impacts of the individual indicators (for a difference of one standard deviation in each of them), but using their estimated coefficients in the overall regressions performed on all five of them (taken together and not in separate regressions), and thus taking into account their intercorrelations through the changes in estimated regression coefficients. The third ones go even one step further in our tentative assessment of the overall IT and RD impacts; they do so by taking fully into account the intercorrelations between our five indicators, that is not only through the changes in estimated regression coefficients, but also through the changes in their "independent" standard deviations (or conditional or partial standard deviations given the other indicators). ${ }^{21}$ One would of course expect that, because our indicators tend to be positively related, our third type of estimated impacts would tend to be smaller than the second type, and these in turn also smaller than the first type. This is indeed confirmed by what we can see in Table 6 , where the differences are often very sizeable, and specially so between the first type of estimated impacts and the other two. This can be seen also in more detail in Tables A5 in Appendix 5, in which for the sake of completeness we document the individual indicator "components" or "contributions" underlying the first and second types of impacts. The differences between these components thus directly reflect the differences between the coefficients in the regressions performed on each indicator taken separately and in the overall regressions with all five indicators included. We see for example that the estimated RD impacts on productivity and average wage are cut down by a factor of roughly 2 in manufacturing and 3 in the services when we go from our first type to our second or third types of estimates (this fall being accounted by the drop in the regression coefficients of both PRD and

20 The simple correlations or regression coefficients with no controls, that is with labor productivity and (unadjusted average wage), provide even stronger evidence, which of course correspond to the fact that our IT and RD indicators are also positively correlated with the capital intensity and general skills control variables.

${ }^{21}$ They are thus simply equal to the standard deviations of the "regression coefficients weighted sums" of the three IT indicators and the two RD indicators respectively. 
PETU, and specially the latter). We see also that there is similar though less pronounced decrease of the estimated IT impacts on productivity and average wage, by a factor of roughly 1.5 in manufacturing and 2 in the services.

If we thus focus on the third type of impacts, which are a priori more sensible and tend to give much more conservative estimates, the picture we have is a consistent one of very strong IT impacts on total factor productivity and adjusted average wage. These are about one third larger for productivity than for average wage, also about one third larger in the services than in manufacturing, and from $15 \%$ (in the services) to $25 \%$ (in manufacturing) higher in the more recent period 1990-1994 than in the first 1986-1990. We find for example that in the recent period the IT impact on productivity, corresponding to differences of one standard deviation in our three related IT indicators, is of about $14 \%$ in manufacturing and $19 \%$ in the services, thus accounting for nearly as much as one third of the standard deviations of firm differences in productivity in these two sectors. ${ }^{22}$

We have also a clear picture of the RD impacts. It is one of impacts which are much smaller than the comparable IT impacts, but nonetheless quite sizeable. They are about the same for productivity and average wage and in the two periods, and nearly twice as large in manufacturing than in the services. The estimated RD impacts corresponding to one standard deviation in our indicators are respectively of about $4.5 \%$ in manufacturing and $2.5 \%$ in the services, accounting for another $10 \%$ of the standard deviation of firm differences in productivity in manufacturing and a more modest $4 \%$ in the services.

\section{5- ... as well as very significant evidence of correlations with skill composition}

In the cross-sectional dimension of the data, the firm level evidence of significant correlations between skill composition and our IT and RD indicators is about as striking as in the case of total factor productivity and adjusted average wage. Focusing again on our third type of estimated impacts, we see that these are particularly strong as concerns the share of blue collar workers (PEP) and of a negative sign consistently with what we also find in the time dimension of the data. This is so in manufacturing and the services and in the two periods, and for both the IT and RD impacts. The magnitude of IT impacts is of about $-12 \%$ in manufacturing and $-8 \%$ in the services,

22 As indicated in Table A2 in Appendix 2, the standard deviation of log labour productivity (LVA/L) is 0.46 in manufacturing and 0.63 in the services, most it corresponding to the between firm (cross-sectional) differences. 
corresponding respectively to nearly two third and one third of the standard deviation of the firm share of blue collar workers in these two sectors. The magnitude of RD impacts is also quite sizeable, of $7 \%$, in manufacturing (about one third of the standard deviation in the firm share of blue collar workers), but appears very weak in the services (of $-1 \%$ ), where research and analysis activities are of much lesser importance.

The estimated IT impacts are also remarquably strong, but of positive sign, on the shares of administrative managers (PCA), showing that a one standard deviation joint increase in our indicators is associated with a rise of about $6 \%$ in the share of this category in manufacturing and in the services, that is as much as two third to one third of the corresponding firm standard deviations in the two sectors. ${ }^{23}$ Compared to these impacts on the shares of blue collar workers and administrative management, all other estimated impacts are relatively weak, or even negligible. We can note that, interestingly enough, the estimated IT impacts on the share of employees (PEA) appear to be positive in manufacturing (of $2 \%$ in the recent period) while negative $(-2 \%)$ in the services.

\section{Conclusion}

Econometric investigations on the relationships between firm characteristics and performances and their IT related investments are far less numerous than those concerned with their investment in research and, more generally, innovation activities. A major reason is no doubt the paucity of statistical information, at least until very lately, on the diffusion and development of the use of IT which is available at the firm level for such studies, and by contrast the relative wealth of information on firm RD expenditures and innovation behavior. Our present estimates on the productivity of $\mathrm{RD}$ and other impacts, although based on our two rather crude RD related indicators, do confirm on the whole the results already found in many comparable firm econometric studies: significant and robust evidence of positive impacts in the cross-section dimension, but much more fragile evidence in the time-series dimension. ${ }^{24}$ Thus, in this brief and provisional

23 The standard deviation of the share of administrators (PCA) in manufacturing appears notably much higher in the second than in the first period, of about $12 \%$ as against $9 \%$; it is of about $18 \%$ in the services (see Table A2 in Appendix 2).

24 For a detailed survey of the econometric literature on productivity and R\&D (which remains relevant although getting old), see Mairesse-Sassenou 1991. For a more general survey (giving in particular the references to a number of other surveys), see Mairesse-Mohnen 1999. 
conclusion, we only try to relate our work to a few econometric studies which have attempted to assess the impacts of IT on firm productivity and skills, and are representative of a still small but very rapidly growing literature. ${ }^{25}$

As in the case of RD, our cross-sectional results based on our three IT related indicators are quite consistent with the ones already obtained in several recent studies. Lichtenberg (1995), Brynjolfsson and Hitt (1995) and Lehr and Lichtemberg (1999) for samples of major American corporations estimate production functions showing a significant positive relation between firm total factor productivity and indicators of the extent of computerization (more or less similar to ours but available from private surveys). Greenan and Mairesse (2000) also find such a relation for France, using an indicator of the proportion of computer users in the firm (although this indicator relies on the answers of only one up to three, randomly matched, employees per firm). Black and Lynch (1997), Doms, Dunne and Troske (1997) and Dunne, Foster, Haltiwanger and Troske (2000), using data on American manufacturing establishments, obtain more or less comparable results. These last two studies also report strong evidence of correlations between computerization (and more generally speaking the adoption of new technologies) and the skill composition of the firm (with lower shares of production workers and conversely higher shares of non-production workers).

In the time-series dimension, our negative findings on the absence of a relation between our IT indicators and the growth of productivity seem largely shared by most of the previously cited authors, when the panel structure of their data enables them to compute within firm type estimates. The studies by Brynjolfsson and Hitt (1995) and by Lehr and Lichtemberg (1999) both nonetheless report evidence of a significant positive relation, as does the study by Siegel (1997), based on highly detailed US manufacturing industry data. In the opposite direction, our within-firm estimates showing significant negative correlations between the changes in the firm share of blue collar workers and our IT indicators are not supported by the results of Doms, Dunne and Troske (1997), nor those of Goux et Maurin (1997) on French industry data; they are consistent, however, with the results found on US industry data by Berndt, Morrisson and Rosenblum (1992) and Autor, Katz and Krueger (1997).

25 For a recent detailed survey of the econometric literature on the relations between skills and wages (and employment) and IT (and more generally technological change) at the firm level (and industry level) see Chennels-Van Reenen 2001. For two surveys of the econometric literature on productivity and IT (the second focusing on the role of organisational change as an enabling complementary factor)complementary already), see Brynjolfsson-Yang 1996 and HittBrynjolfsson 2001. 


\section{REFERENCES}

Autor H., Katz L.F., Krueger A.B. (1997), "Computing Inequality: Have Computers Changed the Labor Market?", NBER Working Paper, $\mathrm{n}^{\circ}$ 5956, March.

Bensaid A., Greenan N., Mairesse J. (1997), "Informatisation, recherche et productivité", Revue Economique, 48(3), 591-603.

Berndt E.R., Morrisson C., Rosenblum L.S. (1992), "High-Tech Capital, Formation and Labor Composition in US Manufacturing Industries: an Exploratory Analysis", NBER Working Paper, $\mathrm{n}^{\circ}$ 4010, March.

Bouabdallah K., Greenan N., Villeval M.C. (1999), "Le biais technologique : fondements, mesures et tests empiriques", Revue française d'Economie, 14(1), 171-227.

Black S., Lynch L. (1997), "How to Compete: the Impact of Workplace Practicses and Information Technology on Productivity", NBER Working Paper, $\mathrm{n}^{\circ}$ 6120, August.

Brynjolfsson E., Hitt L. (1995), "Information Technology as a Factor of Production: The Role of Differences among Firms", Economics of Innovation and New Technology, 3(3-4), 183-199.

Brynjolfsson E., Yang S. (1996), "Information Technology and Productivity: A Review of the Literature", in Advances in Computers, M. Zelkowitz ed., vol. 43.

Chennells L., Van Reenen J. (2001 forthcoming), " Technical Change and the Structure of Emplyment and Wages: A Survey of the Econometric Evidence", in ThePuzzling Relations between the Computer and the Economy, N. Greenan, Y. Lhorty, J. Mairesse eds., The MIT Press.

Cunéo Ph., Mairesse J. (1984), "Productivity and Research-Development at the Firm Level in French Manufacturing" in Research and Development, Patents and Productivity, Z. Griliches ed., The University Press of Chicago, 375-392.

Doms M., Dunne T., Trotske K. (1997), "Workers, Wages and Technology", The Quarterly Journal of Economics, vol. CXII (1), 253-290.

Dunne T., Foster J., Haltiwanger J., Trotske K. (2000), "Wages and Productivity Dispersion in U.S. Manufacturing: The Role of Computer Investment", NBER Working Paper, $\mathrm{n}^{\circ} 7465$, January. 
Goux D., Maurin E. (1997), "Le déclin de la demande de travail non qualifié. Une méthode d'analyse empirique et son application à la France ", Revue Economique, 48, 1091-1114.

Greenan N. (1996), "Progrès technique, changements organisationnels et évolution des compétences", Economie et Statistique, n 198, 35-44.

Greenan N., Mangematin V. (1999), "Informatisation, organisation et performances : autour du paradoxe de productivité" dans Innovations et Performances : Approches interdisciplinaires, D.Foray et J.Mairesse eds., Editions de L'Ecole des Hautes Etudes en Sciences Sociales, Paris, 367-383.

Greenan N., Mairesse J., Topiol Bensaid A.,(1999), "Investissements immatériels, productivité et qualifications ", Revue Economique, 50, 417-430.

Greenan N., Mairesse J. (2000), "Computer and Productivity in France: Some Evidence", Economics of Innovation and New Technology, 9, 275-315.

Griliches Z., Mairesse J. (1998), "Production Functions: The Search for Identification", in Econometrics and Economic Theory in the $20^{\text {th }}$ Century: The Ragnar Frish Centennial Symposium, S.Ström ed., Cambridge University Press, 169-203.

Hitt L., Brynjolfsson E. (2001 forthcoming), "Information Technology, Organizational Transformation and Business Performance ", in ThePuzzling Relations between the Computer and the Economy, N. Greenan, Y. Lhorty, J. Mairesse eds., The MIT Press.

INSEE-DARES (1994), "Nomenclature des professions et catégories socioprofessionnelles des emplois salariés d'entreprises (PCS-ESE)".

Lehr W.,Lichtenberg F. (1999), "Information Technology and its Impact on Productivity: Firm Level Evidence from Government and Private Data Sources", Canadian Journal of Economics, 32, 335-362.

Lichtenberg F. (1995), "The Output Contribution of Computer Equipment and Personnel: A Firm Level Analysis", Economics of Innovation and New Technology, 3, 201-217.

Mairesse J. (1990), "Time-series and Cross-sectional Estimates on Panel Data: Why Are They Different and Why Should They Be Equal?", in J.Hartog, G.Ridder and J.Theeuwes eds., Panel Data and Labor Market Studies, Amsterdam: North-Holland Publishing Co., 81-95.

Mairesse J., Sassenou M.(1991), "R-D and Productivity : a Survey of Econometric Studies the Firm Level", Science-Technology Industry Review, OECD, 8, 9-43. 
Mairesse J., Bensaid A., Greenan N. (2000), “L'apport de l'Enquête Structure des Emplois à la mesure de l'effort de recherche des entreprises", note de travail (version révisée à paraitre), Département des Etudes Economiques d'Ensemble, INSEE.

Mairesse J., Mohnen P. (1999), "Recherche-Developpement, externalités et productivité : un survol de la litterature économétrique", Les Cahiers de l'Innovation $n^{\circ} 99019$, Université de Paris 1 Panthéon-Sorbonne, Eureka, Maison des Sciences Economiques.

Siegel D. (1997), "The Impact of Computers on Manufacturing Productivity Growth: A MultipleIndicators, Multiple-Causes Approach", The Review of Economics and Statistics, 74,68-78. 
Table 1:

Shares of "IT and RD labor"by general skill categories

\section{MANUFACTURING :}

Average employment 86-90 : 1,416,580 (100\%) for sample of 3,064 firms

\begin{tabular}{|l|l|l|l|}
\hline $\mathrm{CA}=130,227$ & $\mathrm{CP}=260,324$ & $\mathrm{EA}=138,119$ & $\mathrm{EP}=887,910$ \\
\hline
\end{tabular}

R\&D ETU RD ETU INF ELEC ETU INF RD ETU ELEC

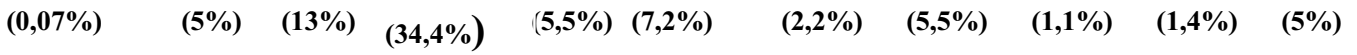

Average employment 90-94 : 1,171,267 (100\%) for sample of 2,951 firms

\begin{tabular}{|l|l|l|l|}
\hline $\mathrm{CA}=122,411$ & $\mathrm{CP}=234,186$ & $\mathrm{EA}=110,838$ & $\mathrm{EP}=703,832$ \\
\hline
\end{tabular}

R\&D ETU RD ETU INF ELEC ETU INF RD ETU ELEC $\begin{array}{lllllllllll}(0,14 \%) & (5 \%) & (13,8 \%) & (33,2 \%) & (6 \%) & (7,3 \%) & (2,7 \%) & (5 \%) & (1,2 \%) & (1,2 \%) & (4,7 \%)\end{array}$

\section{SERVICES}

Average employment 86-90 : 676,195 (100\%) for sample of 2,448 firms

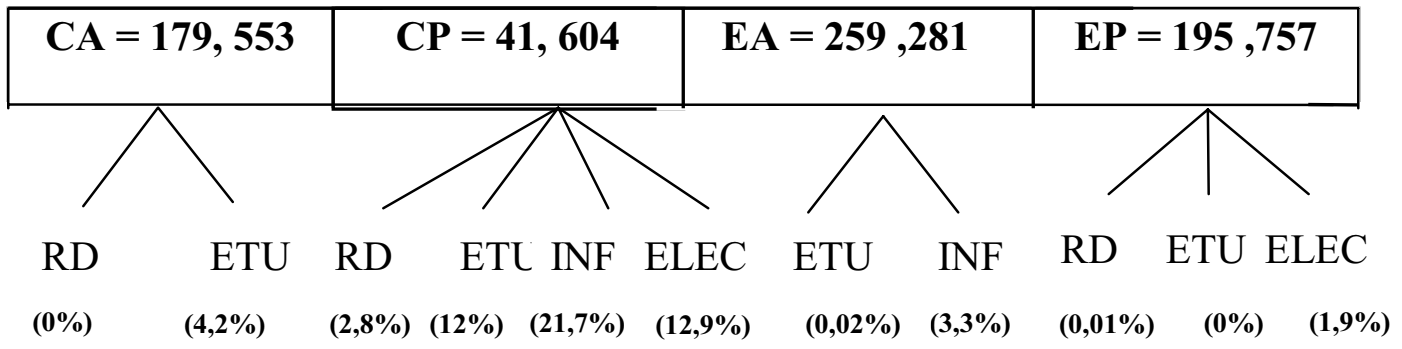

Average employment 90-94 : 599091 (100\%) for sample of 2411 firms

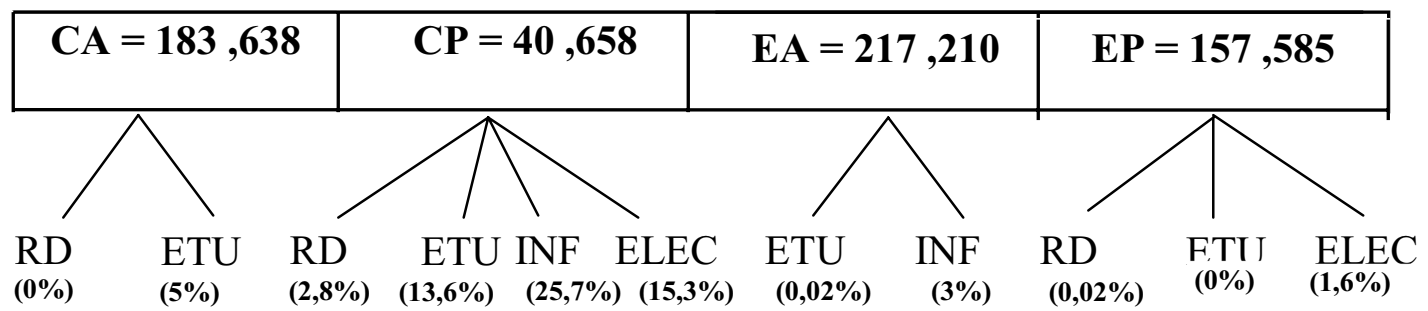


Table 2 :

Shares of "IT and RD labor"

(in \% of total number of employees)

\begin{tabular}{|c|c|c|c|c|}
\hline \multirow{2}{*}{} & \multicolumn{2}{|c|}{ Manufacturing } & \multicolumn{2}{c|}{ Services } \\
\cline { 2 - 5 } & $\mathbf{8 6 - 9 0}$ & $\mathbf{9 0 - 9 4}$ & $\mathbf{8 6 - 9 0}$ & $\mathbf{9 0 - 9 4}$ \\
\hline "Computer staff" (PINF) & 1.5 & 1.7 & 2.6 & 2.8 \\
\hline "Electronics staff" (PELEC) & 4.5 & 4.3 & 1.3 & 1.5 \\
\hline "Research staff" (PRD) & 3.1 & 3.5 & 0.2 & 0.2 \\
\hline "Analysis staff" (PETU) & 7.9 & 7.9 & 1.9 & 2.5 \\
\hline TOTAL & 17.0 & 17.4 & 6.0 & 7.0 \\
\hline
\end{tabular}

Reading: In manufacturing over the period 1986-1990, the (weighted) average share of computer related staff in the total number of employees was $1,5 \%$.

Table 3 :

Shares of "general skill category" after (and before) adjustment

for "double counting" of IT and RD labor

(in \% of total number of employees)

\begin{tabular}{|c|c|c|c|c|}
\hline \multirow{2}{*}{} & \multicolumn{2}{|c|}{ Manufacturing } & \multicolumn{2}{c|}{ Services } \\
\cline { 2 - 5 } & $\mathbf{8 6 - 9 0}$ & $\mathbf{9 0 - 9 4}$ & $\mathbf{8 6 - 9 0}$ & $\mathbf{9 0 - 9 4}$ \\
\hline "Conception and Administration" (PCA) & $8.7(9.2)$ & $9.9(10.5)$ & $25.4(26.6)$ & $29.1(30.7)$ \\
\hline "Conception and Production" (PCP) & $7.3(18.4)$ & $7.9(20.0)$ & $3.0(6.2)$ & $2.9(6.8)$ \\
\hline "Execution and Administration" (PEA) & $9.0(9.8)$ & $8.8(9.5)$ & $37.0(38.3)$ & $35.2(36.3)$ \\
\hline "Execution and Production" (PEP) & $58.0(62.6)$ & $56.0(60.0)$ & $28.6(28.9)$ & $26.0(26.2)$ \\
\hline TOTAL & $83.0(100)$ & $82.6(100)$ & $94.0(100)$ & $93.0(100)$ \\
\hline
\end{tabular}

Reading: In manufacturing over the period 1986-1990, the (weighted) average share of employees in the "conception and administration" general skill category was $8.7 \%$ after adjustment for "double counting" (and 9.2\% before). 
Table 4 :

Shares of "execution general skill categories" among "IT and RD labor"

(in \% of number of employees)

\begin{tabular}{|c|c|c|c|c|}
\hline \multirow{2}{*}{} & \multicolumn{2}{|c|}{ Manufacturing } & \multicolumn{2}{c|}{ Services } \\
\cline { 2 - 5 } & $\mathbf{8 6 - 9 0}$ & $\mathbf{9 0 - 9 4}$ & $\mathbf{8 6 - 9 0}$ & $\mathbf{9 0 - 9 4}$ \\
\hline$\underline{\text { EA and EP if INF- }}$ & 35 & 28 & 49 & 38 \\
\hline$\underline{\text { EA and EP if ELEC- }}$ & 70 & 66 & 41 & 29 \\
\hline$\underline{\text { EA and EP if RD- }}$ & 22 & 21 & 1,5 & 2,5 \\
\hline$\underline{\text { EA and EP if ETU- }}$ & 15 & 12 & 0,5 & 0,5 \\
\hline TOTAL & 33 & 28 & 27 & 22 \\
\hline EA and EP if INF+ELEC+RD+ETU) & & & & \\
\hline
\end{tabular}

Reading: In manufacturing over the period 1986-1990, the (weighted) average share of computer related labor in the two "execution" general skill categories (in administration and production) was $35 \%$. 
Table 5 :

"IT and RD impacts" on skills, average wage and productivity:

statistically significant between (B) and within (W) firm correlations

\begin{tabular}{|c|c|c|c|c|c|c|}
\hline & PCP & PCA & PEP & PEA & LWA & LTPP \\
\hline \multicolumn{7}{|c|}{ Manufacturing } \\
\hline PKI & $\mathrm{B}^{1}(-)$ et $\mathrm{B}^{2}$ & $\mathrm{~B}$ et $\mathrm{W}^{1}$ & $\mathrm{~B}(-)$ et $\mathrm{W}^{2}(-)$ & B & $\mathrm{B}$ et $\mathrm{W}^{1}$ & B \\
\hline PINF & $\mathrm{B}(-)$ & $\mathrm{B}$ et $\mathrm{W}^{2}$ & $\mathrm{~B}(-)$ et $\mathrm{W}(-)$ & $\mathrm{B}$ & B et $W^{1}(-)$ & $\mathrm{B}$ \\
\hline PELEC & $\mathrm{B}^{2}$ et $\mathrm{W}(-)$ & * & $\mathrm{B}(-)$ et $\mathrm{W}(-)$ & $\mathrm{B}^{2}$ and $\mathrm{W}^{1}(-)$ & $\mathrm{B}^{2}$ et $\mathrm{W}^{2}$ & $\bar{B}$ \\
\hline PRD & B et $W^{1}(-)$ & $B$ et $W^{1}(-)$ & $\mathrm{B}(-)$ et $\mathrm{W}(-)$ & B & B & B \\
\hline PETU & $\mathrm{W}^{2}(-)$ & B et $W^{2}(-)$ & $\mathrm{B}(-)$ et $\mathrm{W}(-)$ & B & $\mathrm{B}$ et $\mathrm{W}^{2}$ & $\mathrm{~B}$ et $\mathrm{W}^{2}$ \\
\hline \multicolumn{7}{|c|}{ Services } \\
\hline PKI & B & B & $\mathrm{B}(-)$ & $\mathrm{B}(-)$ & B et $W$ & $\mathrm{~B}$ et $\mathrm{W}^{2}$ \\
\hline PINF & $\mathrm{B}^{1}(-)$ & $\mathrm{B}(-)$ & $\mathrm{B}(-)$ et $\mathrm{W}^{1}(-)$ & $\mathrm{B}(-)$ et $\mathrm{W}(-)$ & $\mathrm{B}$ & $\mathrm{B}$ \\
\hline PELEC & B & B et $W(-)$ & $\mathrm{B}(-)$ et $\mathrm{W}^{2}(-)$ & $\mathrm{B}(-)$ & B & B \\
\hline PRD & * & $B^{1}(-)$ & $\mathrm{B}^{2}(-)$ & $\mathrm{B}(-)$ & $\mathrm{B}$ & $\mathrm{B}$ \\
\hline PETU & B & $\mathrm{B}^{2}(-)$ et $W(-)$ & $\mathrm{B}(-)$ & $\mathrm{B}(-)$ & B et $W$ & $\mathrm{~B}$ et $\mathrm{W}^{2}$ \\
\hline
\end{tabular}

B (W) indicates that the between (within) firm regression coefficient $\alpha(\beta)$ is statistically significant with a positive sign in both period regressions. $\mathrm{B}$ or $\mathrm{W}$ with (-) indicates that the between or within firm regression coefficient is statistically significant with a negative sign. $\mathrm{B}^{1}$ or $\mathrm{W}^{1}\left(\mathrm{~B}^{2}\right.$ or $\left.\mathrm{W}^{2}\right)$ indicates that the between or within firm regression coefficient is statistically significant for the first (second) period only. In general when significant, between firm regression coefficients are significant at a level of confidence of $1 \%$, while within firm regression coefficients are only significant at a level of confidence of 10\%. For actual estimates, see Tables A3-1 to A3-5 in Appendix 3.

Reading: For manufacturing in both periods 1986-1990 and 1990-1994 the between firm regression coefficients of impacts of the five indicators PKI, PINF, PELEC, PRD and PETU on total factor productivity LTFP are all statistically significant and positive, while it is the case only for the within firm coefficient of PETU in the second period. 
Table 6 :

Estimated IT and RD impacts on skills, average wage and productivity

for one standard deviation in IT and RD indicators

\begin{tabular}{|c|c|c|c|c|c|c|c|c|c|c|c|c|}
\hline \multirow[t]{2}{*}{$\%$} & \multicolumn{2}{|c|}{ PCP } & \multicolumn{2}{|c|}{ PCA } & \multicolumn{2}{|c|}{ PEP } & \multicolumn{2}{|c|}{ PEA } & \multicolumn{2}{|c|}{ LWA } & \multicolumn{2}{|c|}{ LTFP } \\
\hline & $86-90$ & 90-94 & $86-90$ & $90-94$ & $86-90$ & $90-94$ & $86-90$ & 90-94 & $86-90$ & 90-94 & 86-90 & $90-94$ \\
\hline \multicolumn{13}{|c|}{ Manufacturing } \\
\hline IT1 & -0.6 & 0.2 & 7.1 & 7.0 & -23.6 & -23.5 & 4.3 & 3.7 & 10.6 & 13.6 & 15.9 & 19.9 \\
\hline IT2 & -0.5 & 0.3 & 5.1 & 5.4 & -18.1 & -18.9 & 0.7 & 2.9 & 7.3 & 10.4 & 12.2 & 16.3 \\
\hline IT3 & -0.4 & 0.4 & 6.0 & 5.2 & -11.5 & -11.8 & 0.8 & 2.1 & 6.9 & 8.8 & 10.9 & 14.0 \\
\hline & & & & & & & & & & & & \\
\hline RD1 & 0.5 & 0.4 & 2.2 & 1.9 & -13.8 & -9.9 & 1.2 & 0.9 & 9.7 & 10.0 & 11.8 & 9.0 \\
\hline RD2 & 0.5 & 0.3 & 1.0 & 1.5 & -8.7 & -8.9 & 0.3 & 0.3 & 6.2 & 6.2 & 5.6 & 5.5 \\
\hline RD3 & 0.5 & 0.3 & 1.7 & 1.2 & -6.6 & -6.6 & 0.2 & 0.2 & 4.5 & 4.5 & 4.6 & 4.8 \\
\hline \multicolumn{13}{|c|}{$\underline{\text { Services }}$} \\
\hline IT1 & 0.5 & 0.9 & 7.2 & 6.9 & -15.0 & -14.4 & -3.1 & -5.9 & 19.0 & 21.4 & 27.8 & 28.8 \\
\hline IT2 & 0.3 & 0.7 & 5.3 & 5.0 & -12.0 & -10.8 & -1.5 & -3.1 & 13.8 & 14. 6 & 20.8 & 20.6 \\
\hline IT3 & 0.5 & 0.5 & 6.4 & 6.4 & -8.8 & -7.5 & -1.6 & -2.0 & 10.9 & 12.3 & 16.2 & 18.8 \\
\hline RD1 & 0.3 & 0.3 & -1.4 & -0.7 & -3.2 & -4.0 & -2.4 & -3.8 & 7.6 & 9.7 & 7.8 & 10.3 \\
\hline RD2 & 0.1 & 0.1 & -1.6 & -1.1 & -1.0 & -1.2 & -1.4 & -2.5 & 3.5 & 3.8 & 2.5 & 3.6 \\
\hline RD3 & 0.2 & 0.1 & -1.2 & -0.9 & -0.9 & -1.0 & -1.0 & -1.9 & 2.6 & 3.0 & 2.2 & 2.6 \\
\hline
\end{tabular}

The "first type of estimated IT and RD impacts" IT1 and RD1 are obtained by summing the separate "contributions" of respectively PKI, PINF and PELEC and of PRD and PETU based on the estimated between firm regression coefficients in the separate regressions on each of these five indicators and for a difference of one standard deviation in each of them. Tables A5-1 and A5-2.in Appendix 5 show these separate contributions.

The "second type of estimated IT and RD impacts" IT2 and RD2 are obtained by summing the separate "contributions" of respectively PKI, PINF and PELEC and of PRD and PETU based on the estimated between firm regression coefficients in the overall regressions on all five indicators, and for a difference of one standard deviation in each of them (as for IT1 and RD1, i.e., not taking into account their intercorrelations). Tables A5-1 and A5-2 in Appendix 5 show these separate contributions.

The "third type of estimated IT and RD impacts" IT3 and RD3, like IT2 and RD2, are based on the estimated between firm regression coefficients in the overall regressions on all five indicators, but for differences in their standard deviations which take into account their intercorrelations (i.e., they are actually equal to the standard deviations of the weighted sum of respectively PKI, PINF and PELEC and of PRD and PETU, using as weights the estimated between firm regression coefficients in the overall regressions on all five indicators).

Reading: For manufacturing over the period 1986-1990 the third type of estimated IT and RD impacts were respectively of $10.9 \%$ and $4.6 \%$. 


\section{APPENDIX 1: $\underline{\text { Data sources on IT and RD indicators }}$}

\section{1 -The firm accounting information (SUSE) and the evaluation of an IT capital indicator}

The general firm accounting information (for value added VA, total labour compensation WL, gross book value of physical or tangible assets $\mathrm{K}$, and also total number of employees $\mathrm{L}$ ), on which we rely in this study, comes from SUSE (or Systeme Unifie de Statistiques d'Entreprises) maintained by INSEE, the French National Institute of Statistics and Economic Studies. SUSE itself is mainly based on the system of firm annual surveys (or EAE for Enquete Annuelle d'Entreprises) and the statistical exploitation of firm fiscal annual declarations on industrial and commercial benefits (or BIC for Benefices Industriels et Commerciaux).

SUSE also provides, but only for a representative sample of firms with more than twenty salaried employees, some detailed information on the composition of tangible assets, allowing in particular to distinguish office and computing equipment from all other forms of equipment ${ }^{1}$ By restricting our study here to this sample of firms, we have thus been able to measure our indicator of IT capital PKI as the ratio of gross book value in office and computing equipment to the gross book value of all tangible assets.

\section{2 - "L'enquête sur la Structure des Emplois (ESE)" and the construction of IT and RD labour indicators}

ESE is an administrative data source based on the collection of annual occupation statements on workers who are disabled, war veterans or members of assimilated groups. Establishments with more than twenty salaried employees are legally bound to give this specific information as well as detailed occupational information for all their employees. More precisely ESE provides information on the distribution of employees according to the exact nature of the posts they occupy, as defined by the four digit level (270 items) of the classification of professions and socio-professional categories (or PCS for Professions et Categories Socio-professionnelles). The total number of employees to be declared is also well defined, corresponding to the total number of salaried workers registered within the establishment on December 31.2

Since we had to use both the ESE information (only available for establishments over twenty employees) and the firm level SUSE accounting data, we restricted our samples to the firms (with more than twenty employees) that could be matched with their establisments. The two sources using the common firm identification number SIREN and having nearly complete coverage, this was done straightforwardly. ${ }^{3}$

1 Tangible assets as defined in the firm's balance sheet include land, buildings, technical installations, industrial and commercial equipment and other assets such as general installations, office and computing equipment, transport equipment, furniture, reusable packaging, etc. Office and computing equipment comprises all types of equipment designed to facilitate administrative tasks and effectively used for that purpose, for example typewriters, calculators, microfiche readers, associated apparatus (photocopiers, offset printers, etc.), photographic and projection equipment, audio-visual equipment (video cameras and recorders), sound equipment and computers; it also includes office furniture .in the fiscal declaration (See Mémento Pratique Francis Lefebvre Comptable, 1988).

2 Each contract, be it part-time or full-time, is counted as one unit, and the following categories are recorded: salaried workers on fixed-term or permanent contracts, on sandwich courses, young workers under eighteen years of age, outworkers, seasonal workers and salaried workers in employment categories requiring particular aptitudes (temporary staff, interns, workers on special youth schemes and apprentices being however excluded).

3 We simply used the detailed occupational information from ESE for the one-establishment firms, and aggregated it over all establishments over twenty employees for the multi-establishments firms. In the two cases we only had to eliminate a small 
The PCS classification is sufficiently precise to make it possible to identify workers which are mainly involved in the management and maintenance of computers and electronic equipments and in research and analytical or design activities. Based on a close reading of job titles and corresponding explanations in this classification, we have been able to delimit our four specialized categories of IT and RD related employees, and hence measure their relative importance in terms of their shares in firm total employment: PINF, PELEC, PRD and PETU.

Similarly (but only based on the two digit PCS classification), we have also been able to construct our four general skill categories along the two dimensions of conception and management versus execution, and production versus administration, that is roughly: engineers and administrators, and blue collar and white collar workers, and measure their shares in firm total employment: PCP, PCA, PEP and PEA. ${ }^{4}$ Table A1 documents the definition of our four specialised staff categories within these four general categories in reference to the two and four digits codes of the PCS classification.

Table A1: Definition of general skill categories and IT and RD related occupations according to the French socio-professional two and four digit classification

\begin{tabular}{|c|c|c|c|c|}
\hline & $\mathbf{C A}$ & EA & $\mathbf{C P}$ & EP \\
\hline $\begin{array}{c}\text { General Skill } \\
\text { categories }\end{array}$ & $23,37,42,43,46$ & $52,53,54,55,56$ & $4,38,47,48$ & $\begin{array}{l}62,63,64,65,67, \\
68,69\end{array}$ \\
\hline $\begin{array}{l}\text { Computer staff } \\
\text { (INF) }\end{array}$ & - & $5414,5415,5416$ & $3828,4791,4792$ & - \\
\hline $\begin{array}{l}\text { Electronics staff } \\
\text { (ELEC) }\end{array}$ & - & - & $\begin{array}{l}3821,4717,4718,4881 \\
4882\end{array}$ & $\begin{array}{l}6202,6215,6216, \\
6217,6218,6313, \\
6711 \\
\end{array}$ \\
\hline $\begin{array}{c}\text { Research staff } \\
\text { (RD) }\end{array}$ & 4327 & - & $\begin{array}{l}3435,3825,3826, \\
3827,4714,4715, \\
4751,4761,4793\end{array}$ & 6254,6294 \\
\hline $\begin{array}{l}\text { Analysis staff } \\
\text { (ET) }\end{array}$ & $\begin{array}{l}3721,3722,3723, \\
3744,4324,4634\end{array}$ & 5428 & $\begin{array}{l}3820,3822,3823, \\
3829,3838,3843, \\
4701,4711,4712, \\
4721,4722,4723, \\
4731,4732,4735, \\
4771,4772,4781, \\
4782,4794\end{array}$ & 6236 \\
\hline
\end{tabular}

Source: Nomenclature des Professions et Catégories Socioprofessionnelles (PCS), index analytique, vol. I and II, edition 1992.

proportion of firms for which the total number of employees obtained in ESE and the total number in SUSE (usually the average annual number) seemed much too different.

${ }^{4}$ Note, however, that these categories are more ambiguous in services than in manufacturing, since they do not really make the distinction between direct and indirect production of services as they do between direct and indirect production of goods. While a blue-collar employee in the manufacturing sector is classified as having a production activity, a white collar employee in the service sector, such as a counter clerk in a bank, although he or she directly produces a service, would generally be classified as having an administrative or commercial activity. 


\section{APPENDIX 2}

Table A2: Means and standard deviations of variables

\begin{tabular}{|c|c|c|c|c|}
\hline \multirow[t]{2}{*}{$\begin{array}{c}\text { Means } \\
\text { (Standard deviations) }\end{array}$} & \multicolumn{2}{|c|}{ Manufacturing } & \multicolumn{2}{|c|}{ Services } \\
\hline & $86-90$ & $90-94$ & 86-90 & $90-94$ \\
\hline PKI (\%) & $\begin{array}{c}6.45 \\
(8.35)\end{array}$ & $\begin{array}{l}7.54 \\
(9.97)\end{array}$ & $\begin{array}{c}13.81 \\
(16.24)\end{array}$ & $\begin{array}{l}14.56 \\
(16.63)\end{array}$ \\
\hline PINF (\%) & $\begin{array}{l}1.22 \\
(2.11)\end{array}$ & $\begin{array}{l}1.25 \\
(1.91)\end{array}$ & $\begin{array}{c}2.54 \\
(4.36)\end{array}$ & $\begin{array}{c}2.59 \\
(4.05)\end{array}$ \\
\hline PELEC (\%) & $\begin{array}{l}2.63 \\
(6.97)\end{array}$ & $\begin{array}{c}2.80 \\
(6.17)\end{array}$ & $\begin{array}{c}1.34 \\
(4.34)\end{array}$ & $\begin{array}{c}1.51 \\
(4.52)\end{array}$ \\
\hline PR\&D (\%) & $\begin{array}{c}2.01 \\
(4.17)\end{array}$ & $\begin{array}{c}2.25 \\
(4.57)\end{array}$ & $\begin{array}{c}0.03 \\
(1.70)\end{array}$ & $\begin{array}{c}0.03 \\
(1.62)\end{array}$ \\
\hline PETU (\%) & $\begin{array}{c}4.50 \\
(5.49)\end{array}$ & $\begin{array}{c}5.24 \\
(6.17)\end{array}$ & $\begin{array}{c}1.77 \\
(4.33)\end{array}$ & $\begin{array}{c}2.10 \\
(5.18)\end{array}$ \\
\hline PCA (\%) & $\begin{array}{l}10.45 \\
(8.99)\end{array}$ & $\begin{array}{c}10.53 \\
(12.10)\end{array}$ & $\begin{array}{c}23.75 \\
(17.79)\end{array}$ & $\begin{array}{c}25.18 \\
(18.81)\end{array}$ \\
\hline PCP (\%) & $\begin{array}{c}7.25 \\
(8.04)\end{array}$ & $\begin{array}{l}7.68 \\
(9.73)\end{array}$ & $\begin{array}{c}4.10 \\
(8.60)\end{array}$ & $\begin{array}{c}3.98 \\
(8.99)\end{array}$ \\
\hline PEA (\%) & $\begin{array}{c}9.51 \\
(7.00)\end{array}$ & $\begin{array}{l}9.18 \\
(7.63)\end{array}$ & $\begin{array}{c}32.31 \\
(21.90)\end{array}$ & $\begin{array}{c}31.97 \\
(22.86)\end{array}$ \\
\hline PEP (\%) & $\begin{array}{c}61.77 \\
(19.45)\end{array}$ & $\begin{array}{c}60.44 \\
(19.62)\end{array}$ & $\begin{array}{c}33.64 \\
(25.74)\end{array}$ & $\begin{array}{l}32.26 \\
(25.86)\end{array}$ \\
\hline $\begin{array}{l}\text { LL (Log number of } \\
\text { employees) }\end{array}$ & $\begin{array}{c}5.26 \\
(1.21)\end{array}$ & $\begin{array}{c}5.23 \\
(1.15)\end{array}$ & $\begin{array}{c}4.76 \\
(1.16)\end{array}$ & $\begin{array}{c}4.75 \\
(1.14)\end{array}$ \\
\hline $\begin{array}{l}\mathbf{L W} / \mathrm{L} \\
\left(\log 10^{3} \text { F/ capita) }\right.\end{array}$ & $\begin{array}{l}5.11 \\
(0.29)\end{array}$ & $\begin{array}{c}5.28 \\
(0.29) \\
\end{array}$ & $\begin{array}{c}5.14 \\
(0.38) \\
\end{array}$ & $\begin{array}{r}5.29 \\
(0.37) \\
\end{array}$ \\
\hline $\begin{array}{l}\text { LVA/L } \\
\left(\log 10^{3} \text { F/ capita }\right)\end{array}$ & $\begin{array}{l}5.48 \\
(0.46)\end{array}$ & $\begin{array}{c}5.65 \\
(0.46)\end{array}$ & $\begin{array}{c}5.54 \\
(0.60)\end{array}$ & $\begin{array}{c}5.70 \\
(0.63)\end{array}$ \\
\hline $\begin{array}{l}\text { LK/L } \\
\text { (Log } 10^{3} \text { F/ capita) }\end{array}$ & $\begin{array}{l}5.02 \\
(0.94)\end{array}$ & $\begin{array}{l}5.35 \\
(0.97)\end{array}$ & $\begin{array}{c}4.81 \\
(1.04)\end{array}$ & $\begin{array}{c}5.10 \\
(1.08)\end{array}$ \\
\hline
\end{tabular}

The means are the unweighted overall averages of the variables. The standard deviations are the cross sectional ones (i.e., computed on $\mathrm{x}_{\mathrm{i} .}$.), but they differ little from the overall standard deviations (i.e., computed on $\mathrm{x}_{\mathrm{it}}$ ). The variables PCA, PCP, PEA and PEP are corrected for "double counts" with respect to PINF, PELEC, PRD and PETU. 


\section{APPENDIX 3}

Table A3-1: Estimated impacts of IT capital (PKI)

on firm productivity, wage and skill performance and employment in the cross-sectional $(\alpha)$ and time-series $(\beta$ and $\gamma)$ dimensions

\begin{tabular}{|c|c|c|c|c|c|c|c|c|c|c|c|c|}
\hline & \multicolumn{2}{|c|}{ PCP } & \multicolumn{2}{|c|}{ PCA } & \multicolumn{2}{|c|}{ PEP } & \multicolumn{2}{|c|}{ PEA } & \multicolumn{2}{|c|}{$\mathbf{L W A}$} & \multicolumn{2}{|c|}{ LTFP } \\
\hline & $86-90$ & $90-94$ & $86-90$ & $90-94$ & $86-90$ & $90-94$ & $86-90$ & $90-94$ & 86-90 & $90-94$ & 86-90 & $90-94$ \\
\hline \multicolumn{13}{|c|}{ Manufacturing } \\
\hline$\alpha$ & -0.02@ & 0.02@ & 0.60@ & 0.50@ & -1.26@ & -1.01@ & 0.33@ & 0.20@ & 1.01@ & 1.00@ & 1.40@ & 1.45@ \\
\hline$\beta$ & -0.00 & 0.03 & $0.09 \#$ & 0.06 & -0.12 & $-0.16 \#$ & -0.01 & 0.03 & 0.24@ & 0.18 & 0.13 & 0.24 \\
\hline$\gamma$ & 0.01 & -0.01 & 0.05 & 0.01 & -0.05 & -0.01 & -0.03 & -0.01 & 0.05 & -0.05 & -0.02 & -0.01 \\
\hline \multicolumn{13}{|c|}{$\underline{\text { Services }}$} \\
\hline$\alpha$ & 0.02@ & 0.02@ & 0.42@ & 0.41@ & -0.50@ & -0.42@ & $-0.05 \#$ & -0.15@ & 0.77@ & 0.88@ & 1.08@ & 1.26@ \\
\hline$\beta$ & -0.00 & -0.01 & 0.07 & 0.04 & -0.07 & -0.05 & 0.01 & 0.01 & $0.16^{*}$ & $0.17^{*}$ & 0.21 & $0.29 *$ \\
\hline$\gamma$ & -0.01 & 0.01 & -0.00 & 0.03 & 0.01 & 0.01 & -0.01 & -0.05 & -0.03 & -0.02 & -0.08 & -0.05 \\
\hline
\end{tabular}

Estimates statistically different from zero at confidence level of $10 \%, 5 \%$ and $1 \%$ are respectively indicated by $(*)$, (\#) and (@). All regressions contain trend terms, together with sector and size indicators. The regressions entitled LWA and LTFP also contain the other control variables LK/L, PCP, PCA and PEP (corrected for double counting with respect to INF, ELEC, RD and ETU). 
Table A3-2: Estimated impacts of IT labor (PINF)

on firm productivity, wage and skill performance and employment

in the cross-sectional $(\alpha)$ and time-series $(\beta$ and $\gamma)$ dimensions

\begin{tabular}{|c|c|c|c|c|c|c|c|c|c|c|c|c|}
\hline & \multicolumn{2}{|c|}{ PCP } & \multicolumn{2}{|c|}{ PCA } & \multicolumn{2}{|c|}{ PEP } & \multicolumn{2}{|c|}{ PEA } & \multicolumn{2}{|c|}{ LWA } & \multicolumn{2}{|c|}{ LTFP } \\
\hline & $86-90$ & $90-94$ & $86-90$ & 90-94 & $86-90$ & $90-94$ & 86-90 & $90-94$ & $86-90$ & 90-94 & $86-90$ & $90-94$ \\
\hline \multicolumn{13}{|c|}{$\underline{\text { Manufacturing }}$} \\
\hline$\alpha$ & -0.19@ & $-0.11 \#$ & 1.06@ & 1.15@ & -3.01@ & -3.37@ & 0.71@ & 0.82@ & 1.01@ & 1.54@ & 1.55@ & 2.14@ \\
\hline$\beta$ & -0.07 & -0.08 & 0.08 & $0.34^{*}$ & $-0.90 \#$ & $-0.97 \#$ & 0.09 & -0.15 & $-0.95 \#$ & 0.34 & -0.47 & 0.55 \\
\hline$\gamma$ & -0.04 & 0.08 & 0.20 & 0.13 & -0.15 & -0.12 & -0.07 & $-0.17 *$ & -0.23 & 0.09 & -0.53 & 0.16 \\
\hline \multicolumn{13}{|c|}{$\underline{\text { Services }}$} \\
\hline$\alpha$ & $-0.06^{*}$ & 0.04 & $-0.17 \#$ & $-0.16 \#$ & -0.61@ & -0.67@ & $-0.21^{*}$ & -0.40@ & 0.68@ & 0.72@ & 1.64@ & 0.96@ \\
\hline$\beta$ & -0.00 & -0.05 & -0.09 & -0.23 & $-0.61 \#$ & -0.23 & -0.28 & $-0.43 \#$ & 0.04 & 0.27 & -0.04 & 0.44 \\
\hline$\gamma$ & -0.01 & 0.02 & 0.18 & 0.12 & -0.10 & -0.02 & -0.08 & -0.08 & -0.36 & -0.11 & -0.36 & -0.38 \\
\hline
\end{tabular}

See footnote Table A3-1 
Table A3-3: Estimated impacts of "ELEC" labor (PELEC)

on firm productivity, wage and skill performance and employment

in the cross-sectional $(\alpha)$ and time-series $(\beta$ and $\gamma)$ dimensions

\begin{tabular}{|c|c|c|c|c|c|c|c|c|c|c|c|c|}
\hline & \multicolumn{2}{|c|}{ PCP } & \multicolumn{2}{|c|}{ PCA } & \multicolumn{2}{|c|}{ PEP } & \multicolumn{2}{|c|}{ PEA } & \multicolumn{2}{|c|}{ LWA } & \multicolumn{2}{|c|}{ LTFP } \\
\hline & $86-90$ & $90-94$ & $86-90$ & $90-94$ & $86-90$ & 90-94 & $86-90$ & $90-94$ & $86-90$ & $90-94$ & $86-90$ & $90-94$ \\
\hline \multicolumn{13}{|c|}{ Manufacturing } \\
\hline$\alpha$ & 0.00 & 0.03@ & -0.02 & -0.02 & -0.97@ & -1.01@ & 0.00 & $0.02 *$ & 0.01 & $0.10 *$ & $0.14^{*}$ & $0.19 \#$ \\
\hline$\beta$ & $-0.08 \#$ & $-0.12 \#$ & -0.12 & -0.10 & -0.65@ & -0.68@ & $-0.09^{*}$ & -0.07 & 0.11 & $0.36^{*}$ & 0.37 & 0.51 \\
\hline$\gamma$ & 0.00 & -0.01 & -0.02 & -0.00 & 0.02 & 0.02 & -0.02 & -0.01 & 0.04 & 0.13 & 0.16 & 0.15 \\
\hline \multicolumn{13}{|c|}{$\underline{\text { Services }}$} \\
\hline$\alpha$ & 0.10@ & 0.10@ & $0.22 @$ & 0.16@ & -1.08@ & -1.04@ & -0.35@ & -0.39@ & 0.94@ & 0.86@ & 1.01@ & 0.87@ \\
\hline$\beta$ & -0.12 & -0.06 & $-0.30^{*}$ & $-0.30 *$ & -0.12 & $-0.44 \#$ & -0.30 & 0.01 & 0.36 & 0.15 & 0.05 & 0.34 \\
\hline$\gamma$ & -0.01 & 0.01 & -0.02 & -0.03 & -0.00 & -0.04 & 0.04 & 0.00 & -0.05 & 0.04 & -0.20 & -0.15 \\
\hline
\end{tabular}

See footnote Table A3-1 
Table A3-4: Estimated impacts of RD labor (PRD)

on firm productivity, wage and skill performance and employment

in the cross-sectional $(\alpha)$ and time-series $(\beta$ and $\gamma)$ dimensions

\begin{tabular}{|c|c|c|c|c|c|c|c|c|c|c|c|c|}
\hline & \multicolumn{2}{|c|}{ PCP } & \multicolumn{2}{|c|}{ PCA } & \multicolumn{2}{|c|}{ PEP } & \multicolumn{2}{|c|}{ PEA } & \multicolumn{2}{|c|}{ LWA } & \multicolumn{2}{|c|}{ LTFP } \\
\hline & $86-90$ & $90-94$ & $86-90$ & $90-94$ & $86-90$ & 90-94 & $86-90$ & $90-94$ & $86-90$ & $90-94$ & $86-90$ & $90-94$ \\
\hline \multicolumn{13}{|c|}{ Manufacturing } \\
\hline$\alpha$ & 0.11@ & 0.07@ & 0.36@ & 0.30@ & -1.65@ & -1.44@ & 0.10@ & $0.07 \#$ & 0.90@ & 0.91@ & 1.84@ & 1.13@ \\
\hline$\beta$ & -0.19@ & -0.04 & $-0.18^{*}$ & -0.14 & $-0.36 \#$ & -0.66@ & 0.02 & -0.00 & 0.27 & 0.05 & 0.23 & 0.28 \\
\hline$\gamma$ & $0.06^{*}$ & 0.00 & 0.07 & -0.00 & -0.09 & 0.03 & -0.02 & -0.05 & -0.04 & 0.10 & -0.04 & 0.36 \\
\hline \multicolumn{13}{|c|}{$\underline{\text { Services }}$} \\
\hline$\alpha$ & -0.02 & 0.06 & -0.57@ & -0.12 & -0.54 & $-0.45^{*}$ & $-0.47 \#$ & -0.97@ & 1.26@ & 1.31@ & 0.82@ & 1.84@ \\
\hline$\beta$ & -0.04 & -0.10 & -0.27 & -0.03 & -0.20 & -0.47 & 0.03 & -0.01 & -0.19 & 0.73 & -0.27 & 0.75 \\
\hline$\gamma$ & -0.01 & -0.01 & -0.10 & 0.20 & 0.20 & -0.12 & -0.13 & -0.03 & -0.41 & 0.06 & -1.41 & 0.49 \\
\hline
\end{tabular}

See footnote Table A3-1 
Table A3-5: Estimated impacts of "ETU" labor(PETU) on firm productivity, wage and skill performance and employment in the cross-sectional $(\alpha)$ and time-series $(\beta$ and $\gamma)$ dimensions

\begin{tabular}{|c|c|c|c|c|c|c|c|c|c|c|c|c|}
\hline & \multicolumn{2}{|c|}{$\mathbf{P C P}$} & \multicolumn{2}{|c|}{ PCA } & \multicolumn{2}{|c|}{ PEP } & \multicolumn{2}{|c|}{ PEA } & \multicolumn{2}{|c|}{$\mathbf{L W A}$} & \multicolumn{2}{|c|}{ LTFP } \\
\hline & $86-90$ & $90-94$ & $86-90$ & $90-94$ & $86-90$ & 90-94 & $86-90$ & $90-94$ & $86-90$ & $90-94$ & $86-90$ & $90-94$ \\
\hline \multicolumn{13}{|c|}{ Manufacturing } \\
\hline$\alpha$ & 0.01 & 0.01 & 0.13@ & 0.09@ & -1.26@ & -1.11@ & 0.14@ & 0.10@ & 1.09@ & 0.94@ & $0.75 \#$ & $0.63 \#$ \\
\hline$\beta$ & -0.07 & $-0.08^{*}$ & -0.08 & $-0.19 \#$ & -0.65@ & -0.65@ & -0.06 & -0.01 & 0.11 & $0.45 \#$ & -0.03 & $0.88 \#$ \\
\hline$\gamma$ & -0.01 & -0.01 & 0.01 & 0.01 & 0.02 & 0.02 & -0.01 & -0.04 & 0.08 & 0.00 & 0.49 & -0.21 \\
\hline \multicolumn{13}{|c|}{$\underline{\text { Services }}$} \\
\hline$\alpha$ & $0.08 \#$ & $0.04 \#$ & -0.10 & $-0.09 *$ & -0.65@ & -0.63@ & -0.36@ & -0.43@ & 1.25@ & 1.46@ & 1.49@ & 1.41@ \\
\hline$\beta$ & -0.09 & -0.00 & -0.53@ & -0.45@ & -0.18 & -0.18 & -0.20 & -0.24 & $0.75 \#$ & $0.48 \#$ & 0.83 & $0.80^{*}$ \\
\hline$\gamma$ & -0.03 & 0.02 & 0.02 & 0.07 & -0.01 & -0.03 & -0.00 & -0.06 & 0.04 & -0.03 & 0.09 & -0.19 \\
\hline
\end{tabular}

See footnote Table A3-1 


\section{APPENDIX 4}

Table A4-1: Estimated impacts of "IT labor" (PINF) on skills,

in the cross-sectional $(\alpha)$ and time-series $(\beta$ and $\gamma)$ dimensions, with "partial and complete adjustment for double counting"

\begin{tabular}{|c|c|c|c|c|c|c|c|c|c|}
\hline & & \multicolumn{2}{|c|}{ PCP } & \multicolumn{2}{|c|}{ PCA } & \multicolumn{2}{|c|}{ PEP } & \multicolumn{2}{|c|}{ PEA } \\
\hline & & $86-90$ & $90-94$ & 86-90 & $90-94$ & $86-90$ & $90-94$ & $86-90$ & $90-94$ \\
\hline \multicolumn{10}{|c|}{ Manufacturing } \\
\hline$\alpha$ & $\begin{array}{l}\mathrm{NC} \\
\mathrm{C} 1 \\
\mathrm{C} 2\end{array}$ & $\begin{array}{c}0.35 @ \\
0.09 \\
-0.19 @\end{array}$ & $\begin{array}{c}0.43 @ \\
0.09 \\
-0.11 @\end{array}$ & $\begin{array}{l}1.11 @, \\
1.11 @ \\
1.06 @\end{array}$ & $\begin{array}{l}1.25 @ \\
1.25 @ \\
1.15 @\end{array}$ & $\begin{array}{l}-3.15 @ \\
-3.15 @ \\
-3.01 @\end{array}$ & $\begin{array}{l}-3.55 @ \\
-3.55 @ \\
-3.37 @\end{array}$ & $\begin{array}{l}1.46 @ \\
0.72 @ \\
0.71 @\end{array}$ & $\begin{array}{l}1.51 @ \\
0.85 @ \\
0.82 @\end{array}$ \\
\hline$\beta$ & $\begin{array}{l}\mathrm{NC} \\
\mathrm{C} 1 \\
\mathrm{C} 2\end{array}$ & $\begin{array}{c}0.13 \\
-0.20 \\
-0.07\end{array}$ & $\begin{array}{c}0.24 \\
-0.20 \\
-0.08\end{array}$ & $\begin{array}{l}0.11 \\
0.11 \\
0.08\end{array}$ & $\begin{array}{l}0.36^{*} \\
0.36^{*} \\
0.34^{*}\end{array}$ & $\begin{array}{l}-0.90 \# \\
-0.90 \# \\
-0.90 \#\end{array}$ & $\begin{array}{l}-1.04 @ \\
-1.04 @ \\
-0.97 \#\end{array}$ & $\begin{array}{c}0.74 @ \\
0.08 \\
0.09\end{array}$ & $\begin{array}{c}0.43 @ \\
-0.13 \\
-0.15\end{array}$ \\
\hline$\gamma$ & $\begin{array}{l}\text { NC } \\
\mathrm{C} 1 \\
\mathrm{C} 2\end{array}$ & $\begin{array}{c}0.00 \\
-0.02 \\
-0.04\end{array}$ & $\begin{array}{l}0.16 \\
0.16 \\
0.08\end{array}$ & $\begin{array}{l}0.18 \\
0.18 \\
0.20\end{array}$ & $\begin{array}{l}0.13 \\
0.13 \\
0.13\end{array}$ & $\begin{array}{l}-0.17 \\
-0.17 \\
-0.15\end{array}$ & $\begin{array}{l}-0.13 \\
-0.13 \\
-0.12\end{array}$ & $\begin{array}{l}-0.09 \\
-0.07 \\
-0.07\end{array}$ & $\begin{array}{l}-0.15 \\
-0.16 \\
-0.17^{*}\end{array}$ \\
\hline \multicolumn{10}{|c|}{$\underline{\text { Services }}$} \\
\hline$\alpha$ & $\begin{array}{l}\mathrm{NC} \\
\mathrm{C} 1 \\
\mathrm{C} 2\end{array}$ & $\begin{array}{c}0.46 @ \\
0.01 \\
-0.06 *\end{array}$ & $\begin{array}{c}0.71 @ \\
0.16 @ \\
0.04\end{array}$ & $\begin{array}{c}-0.15 \\
-0.15 \\
-0.17 \#\end{array}$ & $\begin{array}{c}-0.08 \\
-0.08 \\
-0.16 \#\end{array}$ & $\begin{array}{l}-0.64 @ \\
-0.64 @ \\
-0.61 @\end{array}$ & $\begin{array}{l}-0.68 @ \\
-0.68 @ \\
-0.67 @\end{array}$ & $\begin{array}{l}0.34 @ \\
-0.21^{*} \\
-0.21^{*}\end{array}$ & $\begin{array}{c}0.06 \\
-0.39 @ \\
-0.40 @\end{array}$ \\
\hline$\beta$ & $\begin{array}{l}\mathrm{NC} \\
\mathrm{C} 1 \\
\mathrm{C} 2\end{array}$ & $\begin{array}{c}0.31 @ \\
-0.06 \\
-0.00\end{array}$ & $\begin{array}{c}0.32 @ \\
-0.15 \# \\
-0.05\end{array}$ & $\begin{array}{l}-0.02 \\
-0.02 \\
-0.09\end{array}$ & $\begin{array}{l}-0.18 \\
-0.18 \\
-0.23\end{array}$ & $\begin{array}{l}-0.61 \# \\
-0.61 \# \\
-0.61 \#\end{array}$ & $\begin{array}{l}-0.25 \\
-0.25 \\
-0.23\end{array}$ & $\begin{array}{c}0.34 \\
-0.28 \\
-0.28\end{array}$ & $\begin{array}{c}0.11 \\
-0.08 \\
-0.43 \#\end{array}$ \\
\hline$\gamma$ & $\begin{array}{l}\mathrm{NC} \\
\mathrm{C} 1 \\
\mathrm{C} 2\end{array}$ & $\begin{array}{c}0.03 \\
-0.03 \\
-0.01\end{array}$ & $\begin{array}{c}0.05 \\
-0.01 \\
0.02\end{array}$ & $\begin{array}{l}0.21 \\
0.21 \\
0.18\end{array}$ & $\begin{array}{l}0.12 \\
0.12 \\
0.12\end{array}$ & $\begin{array}{l}-0.11 \\
-0.11 \\
-0.10\end{array}$ & $\begin{array}{l}-0.03 \\
-0.03 \\
-0.02\end{array}$ & $\begin{array}{l}-0.15 \\
-0.08 \\
-0.08\end{array}$ & $\begin{array}{l}-0.14 \\
-0.01 \\
-0.08\end{array}$ \\
\hline
\end{tabular}

NC corresponds to the regressions where PCP, PCA, PEP and PEA are not adjusted for double counts with respect to IT and RD personnel. C1 corresponds to the regressions where PCP, PCA, PEP and PEA are adjusted only for double counts with respect to computer staff (PINF). C2 corresponds to the regressions corrected where PCP, PCA, PEP and PEA are adjusted for double counts with respect to all four categories of IT and RD labor (PINF, PELEC, PRD and PETU).

See also footnote Table A3-1 in appendix 3. 
Table A4-2: Estimated impacts of "RD labor" (PRD) on skills,

in the cross-sectional $(\alpha)$ and time-series $(\beta$ and $\gamma)$ dimensions, with "partial and complete adjustment for double counting"

\begin{tabular}{|c|c|c|c|c|c|c|c|c|c|}
\hline & & \multicolumn{2}{|c|}{ PCP } & \multicolumn{2}{|c|}{ PCA } & \multicolumn{2}{|c|}{ PEP } & \multicolumn{2}{|c|}{ PEA } \\
\hline & & $86-90$ & 90-94 & $86-90$ & 90-94 & $86-90$ & $90-94$ & 86-90 & $90-94$ \\
\hline \multicolumn{10}{|c|}{ Manufacturing } \\
\hline \multirow[t]{3}{*}{$\alpha$} & NC & 0.74@ & $0.72 @$ & 0.38@ & $0.32 @$ & -1.22@ & -1.07@ & $0.10 @$ & $0.05 \#$ \\
\hline & C1 & 0.18@ & $0.12 @$ & 0.37@ & $0.31 @$ & -1.67@ & -1.47@ & $0.10 @$ & $0.05 \#$ \\
\hline & $\mathrm{C} 2$ & 0.11@ & 0.07@ & 0.36@ & 0.30@ & -1.65@ & -1.44@ & 0.10@ & $0.07 \#$ \\
\hline \multirow[t]{3}{*}{$\beta$} & NC & 0.40@ & $0.30 @$ & $-0.19 *$ & -0.14 & -0.05 & -0.14 & 0.01 & -0.02 \\
\hline & C1 & -0.26@ & $-0.13^{*}$ & $-0.18^{*}$ & -0.14 & -0.39\# & -0.71@ & 0.01 & -0.02 \\
\hline & $\mathrm{C} 2$ & -0.19@ & -0.04 & $-0.18^{*}$ & -0.14 & $-0.36 \#$ & -0.66@ & 0.02 & -0.00 \\
\hline \multirow[t]{3}{*}{$\gamma$} & $\mathrm{NC}$ & $0.08^{*}$ & 0.08 & 0.07 & -0.00 & -0.10 & -0.02 & -0.02 & -0.06 \\
\hline & C1 & $0.09 *$ & 0.03 & 0.07 & -0.00 & -0.11 & 0.04 & -0.02 & -0.06 \\
\hline & $\mathrm{C2}$ & 0.06 & 0.00 & 0.07 & -0.00 & -0.09 & 0.03 & -0.02 & -0.05 \\
\hline \multicolumn{10}{|c|}{$\underline{\text { Services }}$} \\
\hline \multirow[t]{3}{*}{$\alpha$} & NC & 1.01@ & 1.32@ & $-0.41 \#$ & -0.02 & -0.15 & -0.34 & $-0.46^{*}$ & -0.96@ \\
\hline & C1 & 0.25@ & $0.42 @$ & -0.59@ & -0.02 & -0.21 & $-0.45^{*}$ & $-0.46^{*}$ & -0.96@ \\
\hline & $\mathrm{C} 2$ & -0.02 & 0.06 & -0.57@ & -0.12 & -0.54 & $-0.45^{*}$ & $-0.47 *$ & -0.97@ \\
\hline \multirow[t]{3}{*}{$\beta$} & NC & 0.69@ & $0.39^{*}$ & -0.30 & -0.00 & -0.34 & -0.35 & -0.05 & -0.03 \\
\hline & C1 & -0.07 & $-0.48 \#$ & -0.32 & -0.00 & -0.55 & -0.48 & -0.05 & -0.03 \\
\hline & $\mathrm{C} 2$ & -0.04 & -0.10 & -0.27 & -0.03 & -0.20 & -0.47 & 0.03 & -0.01 \\
\hline \multirow[t]{3}{*}{$\gamma$} & $\mathrm{NC}$ & 0.06 & 0.01 & -0.17 & 0.18 & 0.24 & -0.16 & -0.12 & -0.03 \\
\hline & $\mathrm{C} 1$ & 0.03 & -0.01 & -0.13 & 0.18 & 0.22 & -0.14 & -0.12 & -0.03 \\
\hline & $\mathrm{C} 2$ & -0.01 & -0.01 & -0.10 & 0.20 & 0.20 & -0.12 & -0.13 & -0.03 \\
\hline
\end{tabular}

See footnote Table A4-1, but with C1 corresponding to the regressions where PCP, PCA, PEP and PEA are adjusted only for double counts with respect to research staff (PRD), not computer staff. 


\section{APPENDIX 5}

Table A5: Detailed estimated IT and RD impacts on skills, average wage and productivity

for one standard deviation in IT and RD indicators

\begin{tabular}{|c|c|c|c|c|c|c|c|c|c|c|c|c|}
\hline \multirow[t]{2}{*}{$\%$} & \multicolumn{2}{|c|}{ PCP } & \multicolumn{2}{|c|}{ PCA } & \multicolumn{2}{|c|}{ PEP } & \multicolumn{2}{|c|}{ PEA } & \multicolumn{2}{|c|}{$\mathbf{L W A}$} & \multicolumn{2}{|c|}{ LTFP } \\
\hline & $86-90$ & 90-94 & $86-90$ & $90-94$ & $86-90$ & $90-94$ & $86-90$ & $90-94$ & $86-90$ & $90-94$ & $86-90$ & $90-94$ \\
\hline \multicolumn{13}{|c|}{ Manufacturing } \\
\hline PKI & -0.2 & 0.2 & 5.0 & 5.0 & -10.5 & -10.1 & 2.8 & 2.0 & 8.4 & 10.0 & 11.7 & 14.5 \\
\hline PINF & -0.4 & -0.2 & 2.2 & 2.2 & -6.3 & -6.4 & 1.5 & 1.6 & 2.1 & 2.9 & 3.2 & 4.1 \\
\hline PELEC & 0 & 0.2 & -0.1 & -0.2 & -6.8 & -7.0 & 0.0 & 0.1 & 0.1 & 0.7 & 1.0 & 1.3 \\
\hline IT1 & -0.6 & 0.2 & 7.1 & 7.0 & -23.6 & -23.5 & 4.3 & 3.7 & 10.6 & 13.6 & 15.9 & 19.9 \\
\hline PRD & 0.5 & 0.3 & 1.5 & 1.4 & -6.9 & -3.0 & 0.4 & 0.3 & 3.7 & 4.2 & 7.7 & 5.1 \\
\hline PETU & 0.0 & 0.1 & 0.7 & 0.5 & -6.9 & -6.9 & 0.8 & 0.6 & 6.0 & 5.8 & 4.1 & 3.9 \\
\hline RD1 & 0.5 & 0.4 & 2.2 & 1.9 & -13.8 & -9.9 & 1.2 & 0.9 & 9.7 & 10.0 & 11.8 & 9.0 \\
\hline \multicolumn{13}{|c|}{$\underline{\text { Second type of impacts }}$} \\
\hline PKI & -0.1 & 0.4 & 4.7 & 4.8 & -8.0 & -7.8 & -0.1 & 1.6 & 6.7 & 8.3 & 10.4 & 13.2 \\
\hline PINF & -0.3 & -0.2 & 0.9 & 1.3 & -3.6 & -4.7 & 0.8 & 1.2 & 0.6 & 1.9 & 1.3 & 2.9 \\
\hline PELEC & -0.1 & 0.1 & -0.5 & -0.7 & -6.5 & -6.4 & 0.0 & 0.1 & 0.0 & 0.2 & 0.5 & 0.2 \\
\hline IT2 & -0.5 & 0.3 & 5.1 & 5.4 & -18.1 & -18.9 & 0.7 & 2.9 & 7.3 & 10.4 & 12.2 & 16.3 \\
\hline PRD & 0.5 & 0.3 & 1.3 & 1.1 & -6.1 & -6.1 & 0.2 & 0.2 & 3.8 & 4.1 & 4.5 & 4.8 \\
\hline PETU & 0.0 & 0.0 & -0.3 & 0.4 & -2.6 & -2.8 & 0.1 & 0.1 & 2.4 & 2.1 & 1.1 & 0.7 \\
\hline RD2 & 0.5 & 0.3 & 1.0 & 1.5 & -8.7 & -8.9 & 0.3 & 0.3 & 6.2 & 6.2 & 5.6 & 5.5 \\
\hline \multicolumn{13}{|l|}{ Services } \\
\hline \multicolumn{13}{|c|}{ First type of impacts } \\
\hline PKI & 0.3 & 0.3 & 6.8 & 6.8 & -8.1 & -7.0 & -0.8 & -2.5 & 12.5 & 14.6 & 17.6 & 21.0 \\
\hline PINF & -0.2 & 0.2 & -0.6 & -0.6 & -2.2 & -2.7 & -0.8 & -1.6 & 2.4 & 2.9 & 5.8 & 3.9 \\
\hline PELEC & 0.4 & 0.4 & 1.0 & 0.7 & -4.7 & -4.7 & -1.5 & -1.8 & 4.1 & 3.9 & 4.4 & 3.9 \\
\hline IT1 & 0.5 & 0.9 & 7.2 & 6.9 & -15.0 & -14.4 & -3.1 & -5.9 & 19.0 & 21.4 & 27.8 & 28.8 \\
\hline PRD & -0.0 & 0.1 & -1.0 & -0.2 & -0.4 & -0.7 & -0.8 & -1.6 & 2.2 & 2.1 & 1.4 & 3.0 \\
\hline PETU & 0.3 & 0.2 & -0.4 & -0.5 & -2.8 & -3.3 & -1.6 & -2.2 & 5.4 & 7.6 & 6.4 & 7.3 \\
\hline RD1 & 0.3 & 0.3 & -1.4 & -0.7 & -3.2 & -4.0 & -2.4 & -3.8 & 7.6 & 9.7 & 7.8 & 10.3 \\
\hline \multicolumn{13}{|c|}{$\underline{\text { Second type of impacts }}$} \\
\hline PKI & 0.1 & 0.2 & 6.6 & 6.6 & -7.5 & -5.8 & 0.6 & -1.0 & 10.1 & 11.8 & 14.6 & 18.4 \\
\hline PINF & -0.2 & 0.1 & -1.5 & -1.4 & -0.8 & -1.4 & -0.9 & -1.3 & 0.5 & 0.4 & 3.0 & 0.4 \\
\hline PELEC & 0.4 & 0.4 & 0.2 & -0.2 & -3.7 & -3.6 & -1.2 & -0.8 & 3.2 & 2.4 & 3.2 & 1.8 \\
\hline IT2 & 0.3 & 0.7 & 5.3 & 5.0 & -12.0 & -10.8 & -1.5 & -3.1 & 13.8 & 14.6 & 20.8 & 20.6 \\
\hline PRD & -0.1 & 0.0 & -0.9 & -0.3 & -0.1 & -0.2 & -0.6 & -1.1 & 1.6 & 1.1 & 0.4 & 1.7 \\
\hline PETU & 0.2 & 0.1 & -0.7 & -0.8 & -0.9 & -1.0 & -0.8 & -1.4 & 1.9 & 2.7 & 2.1 & 1.9 \\
\hline RD2 & 0.1 & 0.1 & -1.6 & -1.1 & -1.0 & -1.2 & -1.4 & -2.5 & 3.5 & 3.8 & 2.5 & 3.6 \\
\hline
\end{tabular}

The "first type of impacts" are based on the estimated between firm regression coefficients in the separate regressions on each of the five indicators PKI, PINF, PELEC, PRD and PETU and for a difference of one standard deviation in each of them. The "second type of impacts" type are based on the estimated between firm regression coefficients in the overall regressions on all five indicators PKI, PINF, PELEC, PRD and PETU, and for a difference of one standard deviation in each of them. All estimated impacts are rounded to the nearest percentage point. See also the footnote to Table 6 in the text. 